\title{
LEGAL IMPLICATIONS OF THE CRIMINAL POLICY OF RETURNING STATE FINANCIAL LOSSES BY CORPORATIONS IN CORRUPTION CRIMINAL ACTS
}

https://doi.org/10.47743/jopafl-2021-22-27

\author{
Idris WASAHUA \\ Student at the Faculty of Law, Brawijaya University, Malang, \\ East Java, Indonesia \\ idriswasahu.fhub@gmail.com \\ Istislam \\ Lecturer at the Faculty Law, Brawijaya University, Malang, \\ East Java, Indonesia

\begin{abstract}
Abdul MADJID
Lecturer at the Faculty Law, Brawijaya University, Malang, East Java, Indonesia

Setyo WIDAGDO

Lecturer at the Faculty Law, Brawijaya University, Malang, East Java, Indonesia
\end{abstract}

\begin{abstract}
The criminal policy of returning state financial losses to corporations as perpetrators of corruption in state financial losses is regulated as additional criminal sanctions in the form of confiscation of goods and payment of replacement money in Article 18 paragraph (1) letter a and letter b of Law Number 31 of 1999 as amended by Law Number 20 of 2001 concerning the Eradication of Corruption Crimes. The purpose of this study is to find out how the legal implications of the criminal policy of returning state financial losses by corporations as perpetrators of criminal acts of corruption are. This research includes normative legal research with several approaches, namely; Historical approach, statutory approach, case approach, and conceptual approach. The results of this study show that the existing criminal policy for recovering state financial losses still has various legal implications which result in non-optimal efforts to recover state financial losses due to corruption in state financial losses committed by corporations.
\end{abstract}

Keywords: Criminal Policy, State Financial Losses, Corruption, Corporation.

\section{Introduction}

Corruption is a crime that has multidimensional negative implications, one of which and the most important is the emergence of state financial losses and the obstruction of the continuity of national development so that it hinders efforts to create a just and prosperous society based on Pancasila and the 1945 Constitution. From a historical perspective Philosophically, and sociologically, the formation of regulations for criminal acts of corruption was motivated by the behavior of state officials who abused state finances in the 1957 era, which began when the Dutch began to leave Indonesia and had to release five large trading companies which were then taken over and managed by the Indonesian government. Furthermore, army officers who were placed by the government as the top 
management in these companies actually misused the finances of these companies for personal gain. (Semma, 2008). Therefore, in the context of Indonesia, corruption itself was originally a legal term that was only limited to state financial losses, so that the focus of the regulation on corruption was a special form of corruption, namely those involving state or regional financial losses or entities. other laws that use capital and or other concessions from the community (Hamzah, 1984). Therefore, it can be stated that the initial idea behind the formation of regulations for criminal acts of corruption is in order to prevent state financial losses. One of the fundamental changes in Law Number 31 of 1999 as amended by Law Number 20 of 2001 concerning the Eradication of Criminal Acts of Corruption (UU PTPK) from the previous law is the regulation on corporations as legal subjects who can be held criminally responsible. The making of corporations as subjects of criminal law in the law on eradicating corruption can not be separated from the factual conditions where corporations are often used as shields as instruments to commit crimes or become instruments to accommodate the proceeds of criminal acts (Atmasasmita, 2013). Among the types of corruption crimes that can be held accountable to corporations in the PTPK Law are corruption crimes related to state financial losses as regulated in Article 2 paragraph (1) and Article 3. The criminal sanctions imposed on corporations for violations of the two articles are only the principal criminal sanctions of a minimum fine of Rp. 200,000,000.00 (two hundred million rupiah) and a maximum of Rp. 1,000,000,000.00 (one billion rupiah) related to the violation of Article 2 paragraph (1), and a fine of at least Rp. 50,000,000.00 (fifty million rupiah) and a maximum of Rp. 1,000,000,000.00 (one billion rupiah) related to the violation of Article 3, with the maximum penalty plus $1 / 3$ (one third). In addition to the principal criminal sanctions of fines, corporations may also be subject to additional criminal sanctions in the form of confiscation of goods and payment of replacement money as regulated in Article 18 paragraph (1) letters a and b of the PTPK Law.

The additional criminal sanction for confiscation of goods and payment of replacement money is a criminal policy intended to restore state financial losses due to corruption in state financial losses committed by perpetrators of criminal acts, including corporations. Viewed from the aspect of criminal policy, the provision of additional criminal sanctions contained in the PTPK Law is a criminal policy in the legislative or formulative stage which is intended as an effort to overcome crime through criminal law as a part of criminal policy. Criminal policy in the formulation stage has a very strategic role because it is a very decisive initial planning stage (Arief, 2013). Therefore it must be done as carefully as possible. This is because errors or weaknesses in the legislative or formulative policy stages are strategic mistakes that can hinder law enforcement efforts in concreto or in the application stage. Legislative or formulative policies are said to be strategic because they provide the basis, direction, substance and limits of judicial or executive authority. This strategic position implies that the weakness of the criminal law formulation policy will affect criminal law enforcement policies and crime prevention policies (Arief, 2012).

If observed carefully, the criminal policy of returning state financial losses by corporations in criminal acts of corruption in the PTPK Law still sets aside various problems which have implications for the non-optimal effort to recover state financial losses by corporations that commit corruption crimes related to state financial losses. Based on this, it is important to study further on how the legal implications of the criminal policy 
of returning state financial losses by corporations as perpetrators of criminal acts of corruption of state financial losses in the law to the return of state financial losses due to corruption of state financial losses that they commit.

\section{Method}

This type of research is normative juridical research, namely legal research conducted by studying and interpreting theoretical matters relating to the principles, conceptions, doctrines, and legal norms related to the criminal policy of returning state financial losses due to corruption by corporations in the Law. -Law Number 31 of 1999 as amended by Law Number 20 of 2001 concerning Eradication of Criminal Acts of Corruption (PTPK Law). The purpose of this study is to find out how the legal implications of the criminal policy of returning state financial losses by corporations in criminal acts of corruption to efforts to recover state financial losses. Some of the approaches used in the research are; Historical approach, statutory approach, case approach, and conceptual approach. The legal materials in this study consist of primary legal materials, secondary legal materials, and tertiary legal materials. Primary legal materials are obtained from laws and regulations, ranging from higher levels to lower laws and regulations, especially those related to corruption and criminal acts by corporations, as well as several court decisions related to research problems. While secondary legal materials are legal materials that provide explanations of primary legal materials, including books, as well as the writings of experts related to the hierarchy of laws and regulations, the basis for the authority to form laws and regulations, and the content of laws and regulations invitation. Secondary legal materials are sourced from textbooks containing the basic principles of legal science along with the views of legal experts who have legal scientific capabilities relevant to research problems. Meanwhile, tertiary legal materials are legal materials that provide instructions or explanations of secondary legal materials that can come from dictionaries, both legal and non-legal, encyclopedias in the field of law, and internet sites related to research problems.

\section{Results and Discussion}

\section{Philosophical Basis for Returning State Financial Losses}

Efforts to recover state financial losses due to corruption in the PTPK Law can only be carried out through additional criminal sanctions for confiscation of goods and payment of replacement money as regulated in Article 18 paragraph (1) letters a and b. Therefore, the two sanctions have a very important position in relation to efforts to recover state financial losses due to the corruption crime of state financial losses. Specifically related to criminal sanctions for confiscation of goods, confiscation of goods or in other terms often also referred to as the return of assets resulting from criminal acts of corruption, it is a means or way to combat profit-oriented criminal acts. According to Fleming as quoted by Purwaning M. Yanuar (Purwaning M. Yanuar, 2007), the return of assets resulting from criminal acts of corruption seen from the perspective of eradicating corruption, is considered as a tool or means to combat criminal acts that are highly profit-oriented, including criminal acts. acquisitions (crimes driven by greed) and organized crimes. In practice and in the most general terms, the return of assets resulting from criminal acts of 
corruption is a multi-step process and branches of a number of complexities, encompassing a number of institutions, including the police (in a broad sense including the customs police, and other investigative bodies, the prosecutor's office). , the court and possibly the recipients of the proceeds of the crime. As with the additional crime of confiscation of goods, the additional penalty of paying replacement money is also one of the criminal policies related to efforts to recover state financial losses due to corruption that will be used in development. This replacement money is more of an action than a crime (Hamzah, 1993).

Therefore, the confiscation of goods or assets related to criminal acts of corruption, loss of state finances and payment of replacement money in the context of returning state financial losses must also be seen in the framework of realizing the responsibility and protection of the state for all people. It is said that, because the criminal act of corruption, the loss of state finances is essentially a crime that causes harm to all people or citizens. In line with this, Yanuar (2007) citing Potter Donald W.'s opinion, said that a criminal act of corruption is an act of taking state-owned assets which results in the state losing its ability to carry out its obligations and responsibilities in the welfare of the community which has implications for the loss of the basic rights of the community to live in prosperity.

In the theory of justice, there is a principle or doctrine of "crimes does not pay", which means that a lawbreaker does not benefit from the unlawful acts he commits. Therefore, every asset he obtained from a crime must be confiscated. This doctrine is very relevant to the criminal sanctions for confiscation of goods as regulated in Article 18 paragraph (1) letter a of the PTPK Law. This is also in line with the basic principle of "give the state what is the state's right". The state's rights contain state obligations which are individual rights of the community, so that the principle is equal and congruent with the principle of "give the people what the people's rights are".

\section{Legal Implication}

As stated above, the criminal policy of returning state financial losses by corporations in criminal acts of corruption in the PTPK Law still sets aside various problems that have implications for the non-optimal effort to recover state financial losses by corporations that commit corruption crimes related to state financial losses as explained above. as follows:

First, criminal sanctions for confiscation of goods and payment of replacement money are used as additional crimes whose application is facultative and not imperative. In contrast to the principal criminal sanctions that are imperative which is the main punishment in a conviction (Hamzah, 1993). Because it is facultative in nature, the legal consequence is whether or not the additional criminal sanctions can be imposed on the defendant, especially the corporation, wholly depends on the judge who will make the decision. Of course, it will be problematic if it is obvious that there is property obtained by the perpetrator from a criminal act of corruption, but the perpetrators, especially corporations, are not subject to these two sanctions.

Second, the confiscation of goods is only limited to goods related to criminal acts of corruption, and not to goods that are not related to criminal acts of corruption. Empirical experience shows that efforts to confiscate the property of perpetrators of corruption do not always run smoothly. On the other hand, various obstacles are often faced by law enforcement officers, including the efforts of perpetrators of corruption to try as much as 
possible to eliminate or hide goods related to the corruption they have committed, or have switched in various ways, either intentionally to eliminate traces of the criminal act of corruption. acquisition of such goods, or for any other reason. As a result, law enforcement efforts to track down, confiscate and seize the goods did not run smoothly as expected. The tracking and confiscation efforts will be even more complex if the perpetrator hides these assets abroad through financial instruments (Yusuf, 2013). Another problem is the effort to prove that the goods to be confiscated as goods related to corruption are not always easy in practice, because corruption related to certain state financial losses is carried out with very sophisticated modes, not to mention the high standard of evidence that must be met (beyond reasonable doubt). This is what makes it difficult for public prosecutors except public prosecutors who are intelligent, thorough and have sufficient knowledge (Yusuf, 2013). Therefore, according to the author, proving the goods to be confiscated as items related to a criminal act is much more difficult than proving an item belonging to the perpetrator that is not related to a criminal act of corruption. To prove the goods belonging to the perpetrator, it is only enough to prove the basis for the rights to the goods, especially goods whose ownership according to law is proven through an authentic letter, such as ownership rights to land which prove ownership with a certificate of ownership. Meanwhile, to prove goods related to a crime, it is not enough to prove a certificate of ownership, but it must also be proven that the acquisition of the goods originates from or is related to a criminal act of corruption. The inability of law enforcement to prove the goods to be confiscated as goods related to criminal acts of corruption will have implications for the non-optimal return of state financial losses. Other problems that can occur due to several conditions that may arise in practice are as follows: First, if the confiscation of goods is successful, but the value is not sufficient to compensate for state financial losses, efforts to recover state financial losses will not be achieved. Second, if the confiscation of goods is not successful, either because the goods are not found or the goods are no longer available, the effort to recover the state financial losses will not be achieved. The risk will be different if the confiscation can also be carried out on property that is not related to a criminal act of corruption.

Third, the confiscation of the property of the convict who does not pay the replacement money can only be carried out no later than 1 (one) month after the decision has permanent legal force. Such a period of time can provide an opportunity for perpetrators of criminal acts, including corporations, to transfer their assets before the decision is made, even when the case handling process has not yet reached the trial stage or is still in the investigation or investigation stage. Empirical facts show that the criminal sanctions for paying replacement money that have been imposed in the decision are not always paid by the convict as expected. Various problems that arise also affect the success of the implementation of additional criminal payments for replacement money, which in the end makes efforts to recover state financial losses not optimal or not achieved.

On a practical level, some of the problems that arise include; First, there are convicts who are not willing to pay any replacement money at all. Second, even if you pay, the amount is not in accordance with the value of the sentence imposed. Third, the prosecutor did not find the assets of the convict who did not pay the replacement money, either in whole or in part, to be confiscated by the prosecutor to be auctioned and the results were put into the state treasury as a substitute for paying the replacement money that was not paid by the convict. The prosecutor did not find the convict's assets either because in 
fact the convict no longer owns the assets, even if the value does not meet the specified value, or because of the difficulties faced by the prosecutor regarding the convict's efforts to hide his assets which are factually still there. Fourth, specifically for non-corporate convicts, they prefer to serve a prison sentence as a substitute rather than paying a substitute money sentence, especially if the value of the substitute money is quite large. Empirical experience like this can be seen in a study at the Pekanbaru Corruption Court, from 20122014 there were 181 sentencing decisions against defendants, one of which was the payment of replacement money. However, from $75 \%$ of the total verdicts, very few convicts pay criminal sanctions and prefer to serve substitute prison sentences (Pardede, 2016). In addition, the legal process for criminal acts of corruption is carried out through fairly long stages and takes a long time, starting from the stages of investigation, investigation, pre-prosecution, prosecution to trial in court. In such a period of time, people who are involved in criminal cases of corruption, especially those related to state financial losses, both individuals and corporations, are very likely to transfer or hide their property, whether related or not related to criminal acts of corruption during the legal process before taking place case decided in court. In some cases, when the convict who is sentenced to pay the replacement money does not pay the replacement money, while the convict is proven to have obtained property from a criminal act of corruption, but the property has been transferred by the convict to another party or has been hidden in any way before the court decision is rendered and has the force of permanent law, so that it cannot be known by the prosecutor, then the confiscation efforts carried out by the prosecutor will be in vain which has implications for not being optimal or not achieving efforts to recover state financial losses. This problem will not occur if the confiscation has been carried out long ago since the beginning of the investigation process. Such provisions regarding the confiscation period of course will not be effective in preventing the perpetrators from hiding their property.

Fourth, the provisions for confiscation of the convict's property if the convict does not pay replacement money are facultative. Article 18 paragraph (2) of the PTPK Law regulates the confiscation of the convict's property if the convict does not pay replacement money. However, the provision for confiscation of the convict's property if the convict does not pay the replacement money is facultative and not imperative. This can be seen from the word "can" contained in the article. As a legal consequence, whether or not the convict's property can be confiscated, specifically a corporation, is entirely dependent on the stance of the public prosecutor. However, if the public prosecutor chooses not to confiscate the convict's property, then this has implications for the non-optimal effort to recover state financial losses, even though the public prosecutor's actions normatively do not violate the provisions of Article 18 paragraph (2) of the PTPK Law.

Fifth, there are no other sanctions if the corporation does not pay the replacement money. In Article 18 paragraph (3) of the PTPK Law, it is determined that: In the event that the convict does not have sufficient assets to pay the replacement money as referred to in paragraph (1) letter b, then he is sentenced to imprisonment for a term that does not exceed the maximum threat of the principal sentence. in accordance with the provisions of this Law and the length of the sentence has been determined in a court decision. However, because corporations cannot be subject to corporal punishment, such as imprisonment or confinement, these provisions cannot be applied to corporate actors, and can only be imposed on non-corporate actors. This is also confirmed in the Regulation of the Supreme 
Court of the Republic of Indonesia Number 05 of 2014 concerning the Additional Penalty of Substitution for Corruption. In Article 7 paragraph (2) which states; "If the corporation is subject to additional punishment for replacement money as referred to in paragraph (1), the corporation cannot be sentenced to substitute imprisonment for replacement money". The provisions of Article 18 paragraph (3) of the PTPK Law which only regulates imprisonment as a substitute if the non-corporate convict assets are not found to be confiscated and auctioned to serve as replacement money payments if the non-corporate convict does not pay replacement money, shows that the PTPK Law does not consider the perpetrators. corporations as perpetrators of corruption, because their orientation is more towards non-corporate actors or natural humans (Amrullah, 2015). The absence of other criminal sanctions for corporations if the corporation does not have sufficient assets to pay compensation as applies to non-corporate actors, in addition to showing the existence of different (discriminatory) treatment between non-corporate actors and corporate actors, it can also pave the way for corporations to not paying the replacement money because they consider that there are no other sanctions due to not paying the replacement money.

Sixth, there is no arrangement for prosecuting corporations that have been disbanded after a crime has occurred. In the PTPK Law, there are several provisions that regulate the legal implications of a suspect who dies. In Article 33, it is determined that for a suspect who dies during an investigation, while in fact there has been a state financial loss, the investigator shall immediately submit the case file resulting from the investigation to the State Attorney or be handed over to the agency that was harmed for a civil lawsuit against the expert. his inheritance. Meanwhile, according to Article 34, it is determined that if the defendant dies during an examination in court, while there has been a real loss of state finances, the public prosecutor immediately submits a copy of the minutes of the trial to the State Attorney or handed over to the aggrieved agency for investigation. civil lawsuits against their heirs. Then according to the provisions of Article 38 paragraph (5), it is stated that if the defendant dies before the verdict is handed down and there is strong enough evidence that the person concerned has committed a criminal act of corruption, the judge on the demands of the public prosecutor determines the confiscation of the items that have been confiscated.

However, the provisions in several articles above can only be applied to noncorporate criminals and not corporate actors. Against corporations themselves, the PTPK Law does not explicitly regulate charges against corporations suspected of committing criminal acts of corruption and loss of state finances that have been dissolved. So that it can be understood that corporations that have been disbanded after the occurrence of a crime cannot be prosecuted and cannot be punished. This is also emphasized in Article 8 paragraph (1) of the Regulation of the Supreme Court of the Republic of Indonesia Number 13 of 2016 concerning Procedures for Handling Criminal Cases by Corporations, which states: "Corporations that have been dissolved after the occurrence of a criminal act cannot be punished..."

According to Bassiouni as stated by Arief (2008), the goals to be achieved by criminals are generally manifested in social interests that contain certain values that need to be protected, among others: Maintenance of public order, and protection of community members from crime, loss or unjustified dangers carried out by others. Based on this view, the absence of a criminal prosecution arrangement against disbanded corporations related to criminal acts of corruption in state financial losses can be seen as an irrational policy. 
This policy is also classified as a policy that is not good in the process of its design and formation, because it does not consider the aspect of returning state financial losses which is one of the main reasons for the formation of the law on eradicating corruption, especially related to the criminal policy of returning state financial losses as regulated in Article 2 paragraph (1) and Article 3 of the PTPK Law. Which policies, according to Bassiouni, as stated by Arief above, cannot protect social interests, protect citizens from crimes, losses or unjustifiable dangers committed by other people in the form of state financial losses incurred.

\section{Conclusion}

The criminal policy of returning state financial losses in the current law on eradicating corruption, still sets aside various problems that have implications for the nonoptimal effort to recover state financial losses, especially for corporations as perpetrators of corruption in state financial losses.

\section{References}

1. Amrullah, M.A. (2015). Politik Hukum Pidana, Perlindungan Korban Kejahatan Ekonomi di Bidang Perbankan Dalam Perspektif Bank Sebagai Pelaku (Offender). Yogyakarta, Genta Publishing.

2. $\quad$ Arief, B.N. (2008). Bunga Rampai Kebijakan Hukum Pidana, Perkembangan Penyusunan Konsep KUHP Baru. Jakarta, Prenadamedia Group.

3. (2013). Kapita Selekta Hukum Pidana. Bandung, PT. Citra Adytia Bakti.

4. ․ (2012). Kebijakan Formulasi Ketentuan Pidana Dalam Peraturan PerundangUndangan. Semarang, Pustaka Magister Semarang.

5. Atmasasmita, R. (2013). Kapita Selekta Kejahatan Bisnis dan Hukum Pidana. First Printed. Jakarta, Fikahati Aneska.

6. Hamzah, A. (1984). Korupsi di Indonesia, Masalah dan Pemecahannya. Jakarta, PT. Gramedia.

$7 . \quad$ (1993). Suatu Tinjauan Ringkas Sistem Pemidanaan Di Indonesia. Jakarta, Akademika Pressind.

8. Lupu, D. (2019). Tax revenue, corruption and good governance in East European Countries. European Union Financial Regulation and Administrative Area, 705.

9. $\quad$ Pardede, R. (2016). Proses Pengembalian Kerugian Negara Akibat Korupsi. Yogyakarta, Genta Publishing.

10. Semma, M. (2008). Negara dan Korupsi, Pemikiran Mochtar Lubis atas Negara, Manusia Indonesia, dan Perilaku Politik. Jakarta, Yayasan Obor Indonesia.

11. Yanuar, P.M. (2007). Pengembalian Aset Hasil Korupsi Berdasarkan Konvensi PBB Anti Korupsi 2003 Dalam Sistem Hukum Indonesia. Bandung, Alumni.

12. Yusuf, M. (2013). Perampasan Aset Koruptor, Solusi Pemberantasan Korupsi di Indonesia. Jakarta, Buku Kompas.

This article is an open access article distributed under the terms and conditions of the Creative Commons Attribution - Non Commercial - No Derivatives 4.0 International License. 